\title{
Research on Evaluation Indicator System for Distribution Channel of Tourism Destination
}

\author{
Dan Yao1, Mu Zhang'* \\ ${ }^{1}$ Department of IT and Laboratory, Shenzhen Tourism College of Jinan University, Shenzhen, China \\ ${ }^{2}$ JNU-UF International Joint Laboratory on IT \& Tourism, Shenzhen Tourism College of Jinan University, Shenzhen, China \\ Email: yaodan@sz.jnu.edu.cn, *zhangmu@163.com
}

How to cite this paper: Yao, D. and Zhang, M. (2017) Research on Evaluation Indicator System for Distribution Channel of Tourism Destination. American Journal of Industrial and Business Management, 7, 1045-1057.

https://doi.org/10.4236/ajibm.2017.79074

Received: August 11, 2017

Accepted: September 11, 2017

Published: September 14, 2017

Copyright (c) 2017 by authors and Scientific Research Publishing Inc. This work is licensed under the Creative Commons Attribution International License (CC BY 4.0).

http://creativecommons.org/licenses/by/4.0/

\begin{abstract}
With competition of tourism destination becoming fiercer, improving distribution channel is an important way to improve competitiveness of tourism destination. The Paper, by using Delphi, AHP and Yaahp, constructs evaluation indicator system on distribution channel of tourism destination, and takes Shenzhen OCT tourist resort as case study to make comparative analysis on indicator importance and actual performance score of OCT tourist resort. The research finds that internal controllable factors of distribution channel play the most important role in its evaluation, of which economic performance and product factor are far from expectation of tourism enterprise managers, and the Paper will provide advice for improving distribution channel of tourism destination from three aspects, including economic performance of distribution channel, product factor and external uncontrollable factors.
\end{abstract}

\section{Keywords}

Tourism Distribution Channel, Evaluation Indicator System, Tourism Destination, OCT Tourist Resort

\section{Introduction}

The State Council issued Some Suggestions to Promote Reform and Development of Tourism in 2015, putting forward "the Belt and Road" and travel "515" strategy and making action plan of "travel + Internet", thus providing a good macro-environment for tourism development. The World Travel \& Tourism Council (WTTC) estimates that Chinese tourism industry contributes more than $10 \%$ to GDP. With rapid development of tourism and fierce competition of tourism destination, tourism enterprises are gradually aware that perfecting and broaden distribution channel is an important method to improve competitiveness 
of tourism destination. Tourism distribution channel in China is diversified, including online trading website, tourism network media website, third-party trading platform and etc. With the maturity of consumer psychology and convenient transportation, tourism vacation has gradually changed from sightseeing to leisure, and tourists change from "package tour" to "DIY tour". China Internet Information Center data show that as of December 2016, 299 million Chinese made traveling reservation online, of which the proportion of booking vacation products accounted for $7.4 \%$. The percentage of online travel bookings for mobile Internet users in China has increased from 33.9\% to 37.7\% [1]. More and more tourists tend to buy tourism destination products through online tourism distribution channels.

The industry and academia gradually realize that development of tourism destination distribution channels directly affects its actual income. Therefore, combing influencing factors of distribution channels, constructing evaluation indicator system on distribution channel of tourism destination, and accurately analyzing and evaluating the distribution channels of tourism destinations are of great significance to regional tourism development.

\section{Literature Review}

\subsection{Tourism Destination}

Tourism destination is a place providing attraction for travelers and equipped with related tourism facilities, which is corresponding to tourist source and tourism transit. Different from general tourist sites or scenic spots, it possesses unique image and perfect regional management and coordination organization, and can motivate potential tourists to travel and achieve tourism purpose [2].

\subsection{Status of Research on Tourism Distribution Channel}

Distribution channel is various structures with independent organization existing in process of providing products or services to customers and commercial clients; in marketing, distribution channel is generally used to transfer commodities (tangible products) from producers to customers; in hospitality industry, it often transfers customers to products: hotels, restaurants, pleasure-boats or planes [3]. In Buhalis's opinion, distribution channel is a way to promote purchase decision by providing enough market information to consumers at proper time and place [4].

In the early 1980s, Bitner \& Boom defined tourism distribution channel as a way for tourism organizations to communicate and sell their products or services [5]. Smith \& Xiao suggested that tourism distribution channels could be regarded as different presentation of tourism supply chain for invisibility and complexity of tourism products [6]. Pearce, from view of tourists, adopted field research method to study distribution channels met by tourists in Rotorua and Wellington of New Zealand, which provided a new perspective for improvement of tourism distribution channels [7]. Reid \& Pearce studied distribution channels of New Zealand outbound tourism from the perspective of national market, 
pointing out development trend and challenges of distribution channels [8]. In recent years, Internet has been greatly affecting tourism industry, thus traditional distribution channel suffering great attack. Therefore, Kazak made a study on transformation of tourism distribution channels, pointing out the development of Internet and rise of E-commerce, and redefining how tourists found and bought products [9]. Kang \& Brewer et al pointed out in the study that traditional and online distribution channels can expand market share, but the coexistence of both will inevitably lead to conflicts [10]. When taking global distribution system (GDS) as a study object, Granados et al. put forward that, tourism distribution channel undergoing re-intermediation shall still meet challenge of disintermediation [11].

\subsection{Status of Research on Tourism Destination Distribution Channel}

Kracht \& Wan studied historical dynamic changes of tourism distribution channels as well as interaction process of Internet and distribution channels with tourism destination as the object of study [12]. Considering "disintermediation" development of existing distribution channels, Law, through interviews, visited traditional travel agencies and hotel managers of Hongkong tourism destination, and studied disintermediation problem of tourism destination distribution channel from view of tourism products and service suppliers and traditional intermediaries [13]. With popularization of Internet technology in China, Chinese scholars have gradually shifted focus of tourism distribution channels to the impact of Internet on tourism distribution channels. In the case of Mount Huangshan, Zhang Chaozhi and You Wang made dynamic analysis on the influence of Internet on distribution channels of Mount Huangshan tourist destination from diachronic view [14].

In summary, the current research of tourism distribution channels mainly from the perspective of different channel members, Which focus on the development status and the trends of tourism distribution channels, the impact of the Internet, channel integration, and the evaluation index items of distribution channels. Distribution channels affect profits of all members in tourism value chain, the current research on tourism distribution channels lacks overall research on distribution channel and evaluation indicator system on overall distribution channel of tourism destination is much less. Therefore, the research, by using Delphi and AHP, constructs evaluation indicator system on distribution channel of tourism destination so as to enrich domestic whole research on distribution channel of tourism destination.

\section{Research Design}

\subsection{Evaluation Hierarchy Design for Distribution Channel of Tourism Destination}

Internal controllable factors greatly affecting development of distribution channel of tourism destination include enterprises and products; external uncontrollable 
factors refer to distribution environment, including economy, social culture, technology, competition and political and legal environment [15]. Good distribution channel of tourism products shall have characteristics with evident continuity, prominent radiativity, comprehensive matching and ideal economic benefits [16]. When choosing evaluation indicators of tourism distribution channel, make comprehensive evaluation by referring to internal and external factors and channel's characteristics.

Then, evaluation hierarchy can be divided into three parts: I. Target hierarchy is a comprehensive evaluation on distribution channels of tourism destination; II. Criterion hierarchy includes internal controllable factor and external uncontrollable factor, and the two also contain several other factors; III. Scheme hierarchy is actual situation of distribution channel of a specific tourist destination.

\subsection{Selection of Evaluation Indicator}

Han Lijiao and Fan Guoyong constructed the two level evaluation index system of marketing channel, involving 25 indexes in 4 aspects [17]. Zhang Shixin and Chen Guiquan put forward 8 specific evaluation indexes of distribution channel efficiency [18]. After consulting previous literatures, evaluation indicator system on distribution channels of tourism destination has been preliminarily established. The indicator system is divided into three levels, and the first level is internal controllable factors and external uncontrollable factors; the second level includes economic performance, tourism products, tourism enterprises, market level, customer perspective and distribution environment; the third level divides the second level into 25 specific indicators [15] [16] [17] [18]. In order to make scientific and representative indicators, the writer interviewed professors of Shenzhen Tourism College of Jinan University and senior director and account manager of Shenzhen CYTS for further screening and sorting of these 25 indicators. The five-grade marking system is adopted, and each score represents different meaning as follows: $1=$ minimal influence, $2=$ little influence, $3=$ certain influence, $4=$ greater influence, $5=$ remarkable influence. Weighted average of collected experts' scores is as Table 1.

Eliminate $\mathrm{D}_{12}$ and $\mathrm{D}_{22}$ below 3 points, namely indicators with little and minimal influence; Although $\mathrm{D}_{19}$ customer satisfaction has a greater influence, it is difficult to balance, and customer satisfaction research on distribution channels can be carried out separately and the research will not have a further study on it, thus, eliminating the indicator; presentation of $\mathrm{D}_{18}, \mathrm{D}_{21}$ and $\mathrm{D}_{23}$ can be respectively changed into effective communication, economical situation and technical level, and at the same time, change No. of $\mathrm{D}_{21}, \mathrm{D}_{23}$ and $\mathrm{D}_{25}$, thus finally getting 22 indicators.

\subsection{Establishment of Evaluation Indicator System}

After determining detailed indicators, make upward induction of indicators, forming three level indicators, and evaluation indicators of each level are developed 
from the evaluation indicators of the previous level, while evaluation indicators of the previous level can reflect its overall evaluation through lower indicators' evaluation. The evaluation indicator system is shown in Table 2.

Table 1. Primary indicator scoring table.

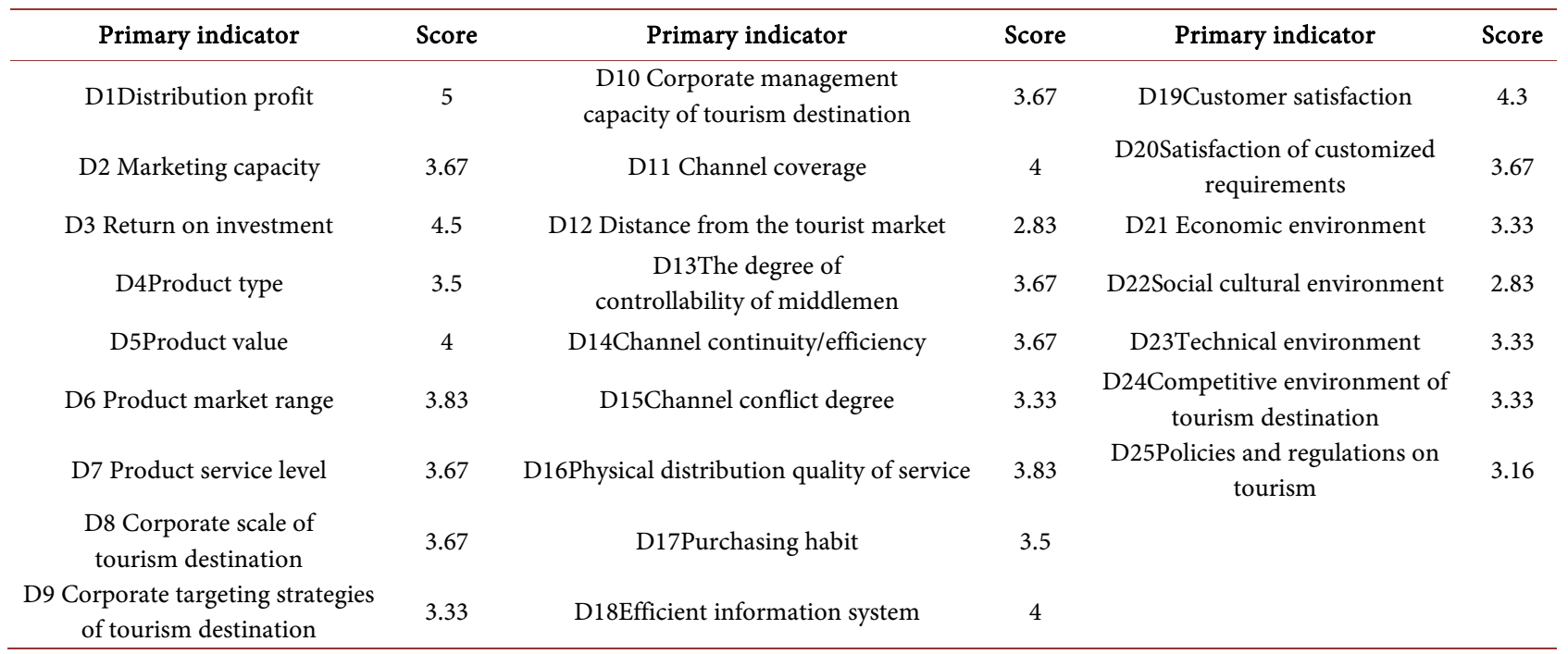

Table 2. Evaluation indicator system on distribution channel of tourism destination.

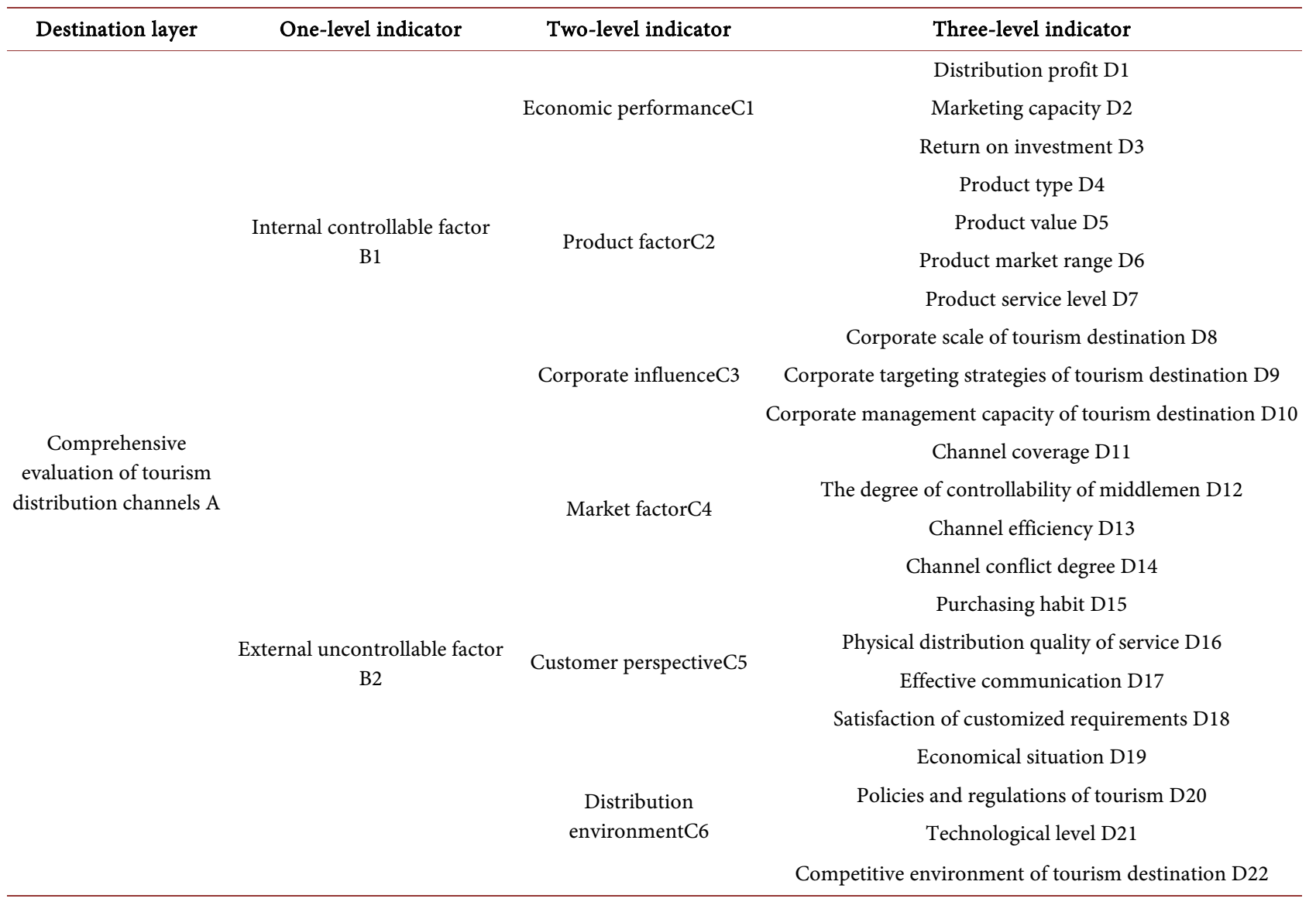

The indicator integration sources: see references [15] [16] [17] [18]. 


\subsection{Scoring of Index Weights}

The research used Delphi and AHP, designed index questionnaire, and collected the influence degree of index on tourism distribution channel. Thus, 5 scholars of Shenzhen Tourism College of Jinan University and Shenzhen University and 4 directors and senior account managers of Shenzhen CYTS MICE Service Co. Ltd have been invited to compare and score indicator questionnaire, getting the relative importance score of each indicator. This questionnaire adopts the 1-9 scale method, by comparing each other to determine the weight of each item on the previous layer.

\subsection{Evaluation Index Weight Determination}

After consistency test, calculate the constructed judgment matrix, input experts' score by Yaahp, getting judgment matrix of each expert's score, and by the group decision making in software, make weighted geometric average for each expert ranking vector, getting combination weights of each indicator (as shown in Table 3).

Table 3. Indicator combination weight.

\begin{tabular}{|c|c|c|c|c|c|c|}
\hline Destination layer & One-level indicator & Weight & $\begin{array}{l}\text { Two-level } \\
\text { indicator }\end{array}$ & Weight & Three-level indicator & Weight \\
\hline \multirow{22}{*}{$\begin{array}{c}\text { Comprehensive } \\
\text { evaluation of tourism } \\
\text { distribution channels } \\
\text { A }\end{array}$} & \multirow{10}{*}{$\begin{array}{c}\text { Internal controllable } \\
\text { factor B1 }\end{array}$} & \multirow{10}{*}{0.7612} & \multirow{3}{*}{$\begin{array}{c}\text { Economic } \\
\text { performance } \mathrm{C} 1\end{array}$} & \multirow{3}{*}{0.3519} & Distribution profit D1 & 0.1752 \\
\hline & & & & & Marketing capacity D2 & 0.0996 \\
\hline & & & & & Return on investment D3 & 0.0771 \\
\hline & & & \multirow{4}{*}{ Product factor C2 } & \multirow{4}{*}{0.2718} & Product type D4 & 0.0355 \\
\hline & & & & & Product value D5 & 0.0773 \\
\hline & & & & & Product market range D6 & 0.0337 \\
\hline & & & & & Product service level D7 & 0.1253 \\
\hline & & & \multirow{3}{*}{$\begin{array}{l}\text { Corporate } \\
\text { influence C3 }\end{array}$} & \multirow{3}{*}{0.1375} & Corporate scale of tourism destination D8 & 0.0892 \\
\hline & & & & & $\begin{array}{c}\text { Corporate targeting strategies of tourism } \\
\text { destination D9 }\end{array}$ & 0.0163 \\
\hline & & & & & $\begin{array}{c}\text { Corporate management capacity of tourism } \\
\text { destination D10 }\end{array}$ & 0.0320 \\
\hline & \multirow{12}{*}{$\begin{array}{c}\text { External } \\
\text { uncontrollable } \\
\text { factor B2 }\end{array}$} & \multirow{12}{*}{0.2388} & \multirow{4}{*}{ Market factor $\mathrm{C} 4$} & \multirow{4}{*}{0.0853} & Channel coverage D11 & 0.0235 \\
\hline & & & & & The degree of controllability of middlemen D12 & 0.0242 \\
\hline & & & & & Channel continuity/efficiency D13 & 0.0291 \\
\hline & & & & & Channel conflict degree D14 & 0.0085 \\
\hline & & & \multirow{4}{*}{$\begin{array}{c}\text { Customer } \\
\text { perspective C5 }\end{array}$} & \multirow{4}{*}{0.0824} & Purchasing habit D15 & 0.0260 \\
\hline & & & & & Physical distribution quality of service D16 & 0.0213 \\
\hline & & & & & Effective communication D17 & 0.0272 \\
\hline & & & & & Satisfaction of customized requirements D18 & 0.0079 \\
\hline & & & \multirow{4}{*}{$\begin{array}{c}\text { Distribution } \\
\text { environment C6 }\end{array}$} & \multirow{4}{*}{0.0711} & Economical situation D19 & 0.0102 \\
\hline & & & & & Policies and regulations of tourism D20 & 0.0087 \\
\hline & & & & & Technological level D21 & 0.0170 \\
\hline & & & & & $\begin{array}{l}\text { Competitive environment of tourism destination } \\
\qquad \text { D22 }\end{array}$ & 0.0351 \\
\hline
\end{tabular}




\subsection{Indicator Weight Analysis}

From the point of view of the combination weight of one-level indicator, the influence of $\mathrm{B} 1$ on distribution channel is greater, up to $75.12 \%$ while $\mathrm{B} 2$ only accounts for $23.88 \%$ when the tourism destination distribution channel is evaluated. Internal controllable factors refer to what can be adjusted internally by tourism enterprises to adapt distribution channel with current situation, and considering it as evaluation focus, together with external uncontrollable factors, enterprises constantly improve the distribution channels.

From the combination weight distribution of two-level indicators, $\mathrm{C} 1$ weight of internal controllable factors is the largest, reaching $35.19 \%$, followed by C2 weight of $27.18 \%$, which is in line with economy in evaluation criteria of distribution channels. Economic standard is the basic starting point of tourism destination enterprise marketing. Therefore, when choosing distribution channels, enterprises should pay more attention to economic performance. The benefits of tourism products are complex, and product factors can influence channel revenue, and its impact on channel evaluation cannot be ignored. From the external uncontrollable factors, weight of $\mathrm{C} 4$, compared to $\mathrm{C} 5$ and $\mathrm{C} 6$, is slightly larger, reaching $8.53 \%$. Obviously, market factor and choice of channel type are closely related, and the channel evaluation and improvement also must be considered from market factor.

From the combination weight of three-level indicator, in detailed indicators, D1 and D7 weights rank top one and top two, reaching $17.52 \%$ and $12.53 \%$, and D7 indirectly influences D1. Economic efficiency is the most important factor for enterprises to evaluate distribution channels; in improving distribution channels, product service levels and product value shall also be improved so as to increase distribution profits. The weight of $\mathrm{C} 3$ is less than $\mathrm{C} 1$ and $\mathrm{C} 2$, but compared to weight of other three-level indicators, the weight of D8 in C3 is relatively large, indicating that corporate scale of tourism destination is the basis of distribution channel selection and design, and corporate actual situation shall be considered to choose proper channel when improving distribution channels.

\section{Empirical Research}

\subsection{Generalization on Object of Research}

Shenzhen OCT tourist resort, with coverage of 4.8 square kilometers, has four large cultural theme parks, Splendid China, China Folk Culture Village, Windows of the World and Happy Valley, visited by more than 6 million people every year. There are also more than 20 cultural entertainment, tourism and leisure facilities and various hotel facilities, including art gallery, art center, School of Tourism, public recreational parks, sports clubs, large shopping plaza and etc. For having the most concentrated cultural theme park group, cultural theme hotel groups and cultural facility group in China, it becomes the first batch of Chinese 5A grade scenic spot, the first batch of national civilized scenic area and national cultural industry demonstration zone. 
OCT tourist resort, following the pace of Internet development, chooses distribution channel conforming to its own development and the times, which becomes the important work of its profit channel diversification. As a representative tourism destination, development of distribution channel of Shenzhen OCT tourist resort has a certain reference function for the development of other tourism destinations.

\subsection{Empirical Data Collection}

Evaluation indicator system on distribution channel of tourism destination is constructed above, and 12 managers, business dealers and salesmen of Shenzhen OCT tourist resort were invited to score for importance of evaluation indicator and its actual performance in OCT tourist resort. The score is divided into nine points, corresponding to scoring system adopted in determining indicator weight.

\subsection{Comprehensive Score}

By weighted average, calculate indicator importance score and actual performance score of OCT tourist resort, seeing Table 4.

\section{Analysis and Results}

\subsection{Scoring Comparison of One-Level Indicator}

The one-level indicator includes internal controllable factors and external uncontrollable factors, with weights of $76.12 \%$ and $23.88 \%$ respectively. It is shown in Figure 1 that the internal controllable factors of OCT tourist resort have greater influence on distribution channel evaluation and score differences, with indicator importance score of internal controllable factors of 1.2391 and actual performance score of OCT tourist resort of 0.9016. It shows that OCT tourism resort should pay attention to improving internal controllable factors when perfecting distribution channel.

\subsection{Scoring Comparison of Two-Level Indicator}

By analyzing scores of one-level indicator and two-level indicator, general direction and detailing direction of improvement of tourism distribution channels can be respectively gotten. As can be seen from Figure 2, distribution channels of OCT tourism resort are deficient in $\mathrm{C} 1$ and $\mathrm{C} 2$ indicators. The weights of the two two-level indicators are $35.19 \%$ and $27.18 \%$ respectively. The $\mathrm{C} 1$ indicator importance score is 0.9066 , and the actual performance is 0.8156 ; the $\mathrm{C} 2$ indicator importance score is 0.5727 and the actual performance is 0.2348 . C1 and C2 are internal factors, indicating that distribution channels of OCT tourist resort need to be further improved in terms of internal controllable factors, economic performance haven't reached the expected goal of management of scenic spot and product added value and level also need to be improved. Although various indicators importance score and actual performance scores of OCT tourist resort 
Table 4. Indicator importance and actual performance score of OCT tourist resort.

\begin{tabular}{|c|c|c|c|c|c|}
\hline Destination layer One-level indicator & $\begin{array}{l}\text { Two-level } \\
\text { indicator }\end{array}$ & Three-level indicator & Weight & $\begin{array}{c}\text { Indicator } \\
\text { importance } \\
\text { score } \\
\end{array}$ & $\begin{array}{c}\text { Actual } \\
\text { performance score of } \\
\text { OCT tourist resort }\end{array}$ \\
\hline \multirow{10}{*}{$\begin{array}{l}\text { Internal controllable } \\
\text { factor B1 }\end{array}$} & \multirow{3}{*}{$\begin{array}{c}\text { Economic } \\
\text { performance C1 }\end{array}$} & Distribution profit D1 & 0.1752 & 7.25 & 6.67 \\
\hline & & Marketing capacity D2 & 0.0996 & 7.50 & 6.25 \\
\hline & & Return on investment D3 & 0.0771 & 7.25 & 6.83 \\
\hline & \multirow{4}{*}{ Product factor C2 } & Product type D4 & 0.0355 & 6.50 & 6.25 \\
\hline & & Product value D5 & 0.0773 & 7.50 & 5.58 \\
\hline & & Product market range D6 & 0.0337 & 7.5 & 6.25 \\
\hline & & Product service level D7 & 0.1253 & 8.33 & 7.58 \\
\hline & \multirow{3}{*}{$\begin{array}{l}\text { Corporate } \\
\text { influence C3 }\end{array}$} & $\begin{array}{c}\text { Corporate scale of tourism } \\
\text { destination D8 }\end{array}$ & 0.0892 & 7.92 & 7.33 \\
\hline & & $\begin{array}{l}\text { Corporate targeting strategies of } \\
\text { tourism destination D } 9\end{array}$ & 0.0163 & 7.92 & 6.50 \\
\hline & & $\begin{array}{l}\text { Corporate management capacity } \\
\text { of tourism destination D10 }\end{array}$ & 0.0320 & 7.67 & 6.75 \\
\hline \multirow{12}{*}{$\begin{array}{l}\text { Comprehensive } \\
\text { evaluation of tour- } \\
\text { ism distribution } \\
\text { channels A }\end{array}$} & \multirow{4}{*}{ Market factor C4 } & Channel coverage D11 & 0.0235 & 7.83 & 6.33 \\
\hline & & $\begin{array}{l}\text { The degree of controllability of } \\
\text { middlemen D12 }\end{array}$ & 0.0242 & 7.17 & 6.42 \\
\hline & & $\begin{array}{l}\text { Channel continuity/efficiency } \\
\text { D13 }\end{array}$ & 0.0291 & 7.75 & 5.92 \\
\hline & & Channel conflict degree D14 & 0.0085 & 6.33 & 5.42 \\
\hline & & Purchasing habit D15 & 0.0260 & 8.17 & 7.08 \\
\hline & Customer & $\begin{array}{c}\text { Physical distribution quality of } \\
\text { service D16 }\end{array}$ & 0.0213 & 8.00 & 6.92 \\
\hline & perspective C5 & Effective communication D1 & 0.0272 & 7.92 & 7.25 \\
\hline & & $\begin{array}{l}\text { Satisfaction of customized } \\
\text { requirements D18 }\end{array}$ & 0.0079 & 7.67 & 5.83 \\
\hline & & Economical situation D19 & 0.0102 & 7.75 & 6.67 \\
\hline & Distribution envi- & $\begin{array}{l}\text { Policies and regulations of } \\
\text { tourism D20 }\end{array}$ & 0.0087 & 7.67 & 7.33 \\
\hline & ronment $\mathrm{C} 6$ & Technological level D21 & 0.0170 & 7.58 & 6.92 \\
\hline & & $\begin{array}{l}\text { Competitive environment of } \\
\text { tourism destination } \mathrm{D} 22\end{array}$ & 0.0351 & 8.08 & 8.00 \\
\hline
\end{tabular}

are different, its impact on the comprehensive evaluation results is relatively small for the indicator weight is small.

\subsection{Scoring Comparison of Three-Level Indicator}

The three-level indicator is the refinement of two-level indicator, and by analyzing three-level indicator score, deficiencies and improvement of distribution channels of OCT tourism resort can be further understood. As can be seen from Figure 3, the performance in each indicator of distribution channels of OCT tourist resort has not reached the expectations of managers, especially in D5, D2, D1 and D7 indicators. In the four indicators, there are main reasons causing actual performance score of OCT tourist resort lower than indicator importance 

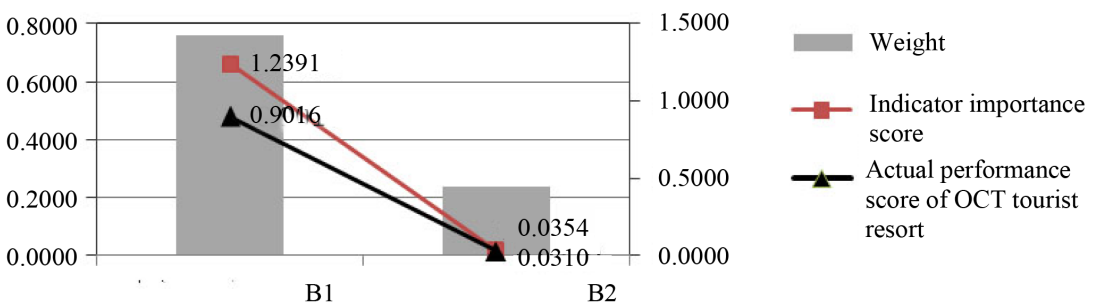

Figure 1. Scoring comparison of one-level indicator.

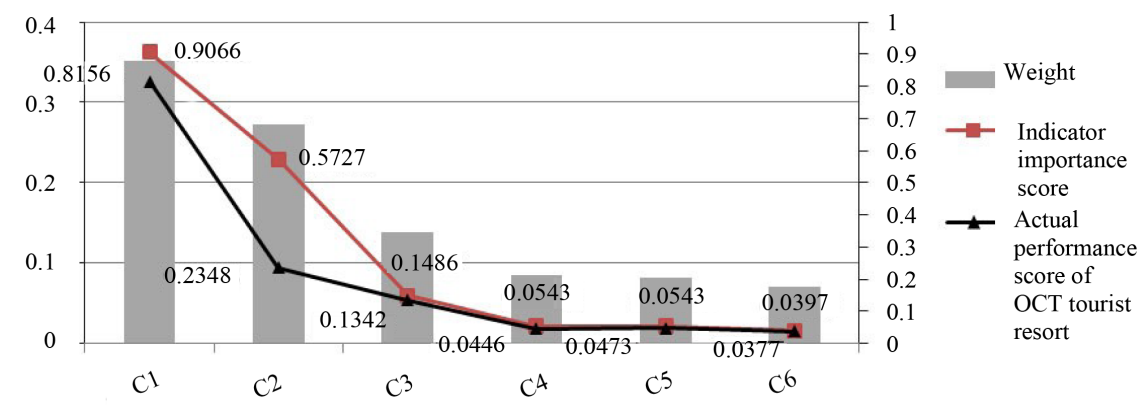

Figure 2. Scoring comparison of two-level indicator.

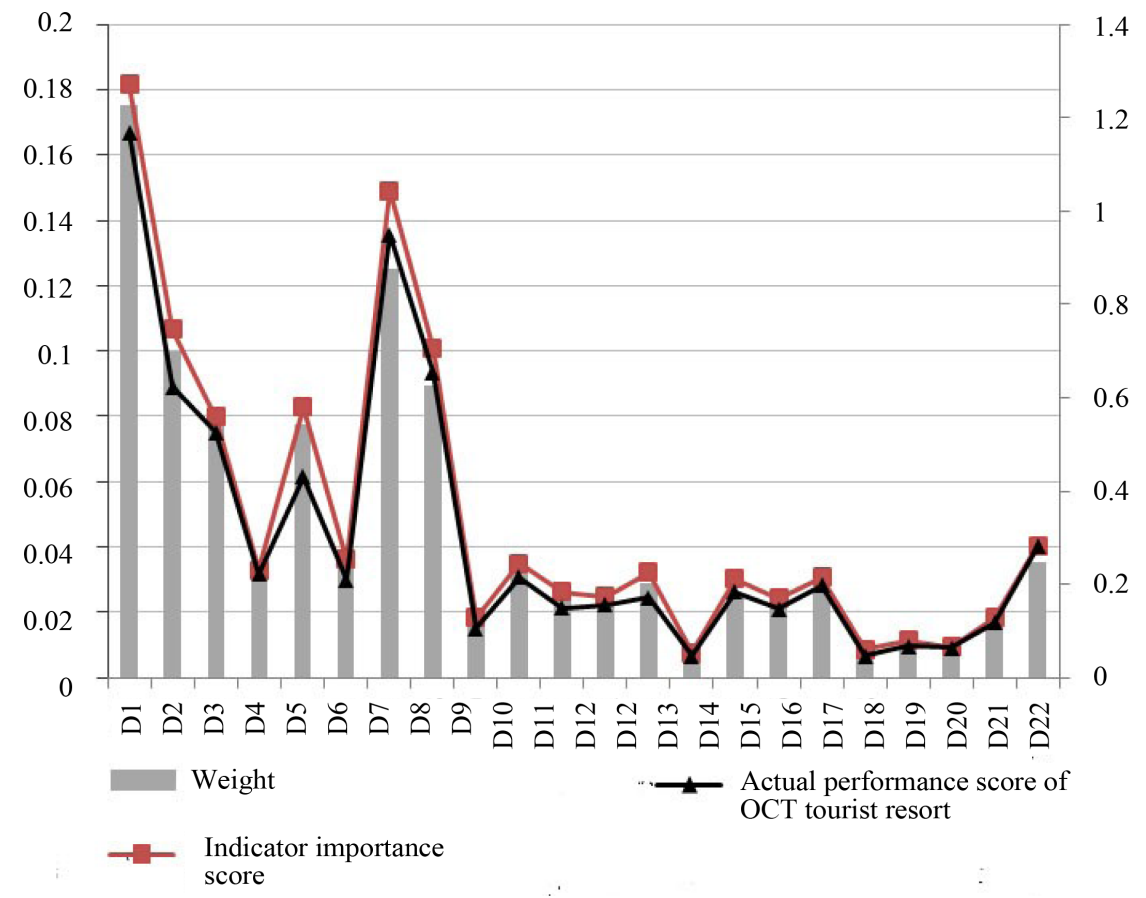

Figure 3. Scoring comparison of three-level indicator.

score: (1) Distribution channels of OCT tourist resort is not up to the management goals in these four aspects, namely the distribution channels in these four areas need to be improved first. Therefore, the staff of this scenic spot scored performance of OCT tourist resort lower than the indicator importance; (2) The four indicators are internal controllable factors, with high weight in evaluation system, further widening the gap between the score, causing more obvious difference 
between importance score and performance score.

\subsection{Comprehensive Evaluation}

The destination layer of the empirical study is the comprehensive evaluation of Shenzhen OCT tourist resort distribution channels. The comprehensive evaluation score of indicator or of OCT tourist resort distribution channel = importance score or actual performance score. The results are as follows: comprehensive evaluation score of indicator importance in OCT tourist resort distribution channels is 7.6181 while the actual performance is 6.7345 , whose difference shows that the evaluation indicator system of this research can make comprehensive evaluation on tourism destination distribution channels based on detailing three-level indicators; differences between actual performance and the expected goals of tourism destination can be gotten according to managers' score, and then tourism destination distribution channels can be adjusted according to these differences.

Through the analysis of indicators in various levels and comprehensive evaluation, the following three problems are verified: (1) The existing distribution channels of OCT tourist resort is insufficient, having not reached the expected target of scenic managers and operators; (2) Internal controllable factors of tourism distribution channel greatly influence the distribution channel development, so the internal controllable factors adjustment is the focus aspect to improve distribution channel; (3) Analysis of field survey data demonstrates reasonability and scientificity of evaluation indicator system on distribution channels of tourism destination, having certain reference significance to the research on the evaluation of distribution channels.

\section{Conclusions}

The research constructs the evaluation indicator system on distribution channel of tourism destination, in which indicator weight shows that the influence of internal controllable factors on the distribution channel is greater than external uncontrollable factors, especially for its economic performance and product factor. These two indicators greatly affect the evaluation of tourism destination distribution channels, which is the focus of enterprises in choosing or improving distribution channels.

Through empirical research on OCT tourist resort, it is found that its distribution channels are quite far from expectation of managers in internal controllable factors, especially in the aspects of product value, marketing capacity, distribution profit and product service level, to which attention needs to be paid for improvement. According to the results of empirical research and tourism environment, the research puts forward the following advice for improving distribution channels of OCT tourist resort: (1) Improve product value to weaken consumer price sensitivity; (2) Make full use of the Internet to improve product sales and reduce channel costs; (3) Share benefits with channel intermediaries to 
achieve win-win business; (4) Use big data skillfully from customer perspective.

The research has some defects such as small number of experts interviewed, selection of evaluation incomprehensive selection of evaluation indicators, inadequate evaluation system and etc. The research just took OCT tourist resort as investigation object. In the future, two similar tourist destinations can be chosen for the study on distribution channel evaluation. Using comparative analysis of both scores of distribution channels, analysis results and suggestions will be more meaningful. Therefore, the evaluation indicator system on distribution channel of tourism destination needs to be further amended and verified in subsequent research.

\section{Acknowledgements}

1) Shenzhen Special Economic Zone constructing first-class tourism management discipline and professional countermeasures, 2015.12-2017.12, a major bidding project of Shenzhen education science plan in 2015, project number: ybzz15002 1.

2) Design and application of cooperative education and innovation mechanism of tourism and cultural industry for special economic zones (Notice on the Special Funds for Comprehensive Reform of Educational System in Guangdong (YCJ [2014] No. 564) and Notice of Guangdong Education Department on Special Funds Management for Comprehensive Reform of Educational System in Guangdong (YJGH [2015] No. 9), 2014.12-2016.12, Guangdong comprehensive reform pilot projects in the field of further education in 2014.

\section{References}

[1] Office of the Central Leading Group for Cyberspace Affairs, Cyberspace Administration of China, China Internet Network Information Center. Report on Development of China's Internet.

http://www.cnnic.net.cn/hlwfzyj/hlwxzbg/hlwtjbg/201701/P02017012336467265740 8.pdf

[2] Ma, Y. and Zhang, X.S. (2008) Review of Domestic Tourism Destination Research. World Regional Study, 17, 144-153.

[3] Kotler, P., Bowen, J. and Makens, J.C. (2002) Tourism Marketing (translated by XieYanjun). 2nd Edition, Tourism Education Press, Beijing, 495-499.

[4] Buhalis, D. and Costa, C. (2000) Introduction: Global Alliances in Tourism and Hospitality Management. International Journal of Hospitality \& Tourism Administration, 1, 1-10.

[5] Bitner, M.J and Booms, B.H. (1982) Trends in Travel and Tourism Marketing: the Changing Structure of Distribution Channels. Journal of Travel Research, 20, 39-44. https://doi.org/10.1177/004728758202000409

[6] Smith, S.L.J. and Xiao, H. (2008) Culinary Tourism Supply Chains: A Preliminary Examination. Journal of Travel Research, 3, 289-299. https://doi.org/10.1177/0047287506303981

[7] Pearce, D.G. and Schott, C. (2005) Tourism Distribution Channels: The Visitors' Perspective. Journal of Travel Research, 44, 50-63. https://doi.org/10.1177/0047287505276591 
[8] Reid, L. and Pearce, D.G. (2008) Distribution Channels for New Zealand Outbound Tourism. International Journal of Tourism Research, 10, 577-592. https://doi.org/10.1002/jtr.696

[9] Kozak, N. (2007) Transformation of Tourism Distribution Channels: Implications of e-Commerce for Turkish Ravel Agencies. Journal of Hospitality \& Leisure Marketing, 15, 95-119. https://doi.org/10.1300/J150v15n02_06

[10] Kang, B., Brewer, K.P. and Baloglu, S. (2007) Profitability and Survivability of Hotel Distribution Channels: An Industry Perspective. Journal of Travel \& Tourism Marketing, 22, 37-50. https://doi.org/10.1300/J073v22n01_03

[11] Granados, N.F., Kauffman, R.J. and King, B. (2008) How Has Electronic Travel Distribution Been Transformed? A Test of the Theory of Newly Vulnerable Markets. Journal of Management Information Systems, 25, 73-95. https://doi.org/10.2753/MIS0742-1222250204

[12] Kracht, J. and Wang, Y. (2010) Examining the Tourism Distribution Channel: Evolution and Transformation. International Journal of Contemporary Hospitality Management, 22, 736-757. https://doi.org/10.1108/09596111011053837

[13] Law, R. (2015) Distribution Channel in Hospitality and Tourism Revisiting Disintermediation from the Perspectives of Hotels and Travel Agencies. International Journal of Contemporary Hospitality Management, 27, 431-452. https://doi.org/10.1108/IJCHM-11-2013-0498

[14] Zhang, C.Z. and Wang, Y. (2012) Influence of Internet on Tourist Destination Distribution Channels in Mount Huangshan. Tourism Tribune, 27, 59.

[15] Li, X.G. (2007) Distribution Channel Management. Tsinghua University Press, Beijing, 11-14.

[16] Zhao, X.P. (2002) Tourism Marketing. Higher Education Press, Beijing, 221-223.

[17] Han, L.J. and Fan, G.Y. (2006) Establishment of Evaluation Indicator System on Marketing Channel. Business Research, 8, 20-21.

[18] Zhang, S.X. and Chen, G.Q. (2011) Research on Efficiency Evaluation Indicators of Distribution Channel. Market Modernization Magazine, 21, 32-33.

Submit or recommend next manuscript to SCIRP and we will provide best service for you:

Accepting pre-submission inquiries through Email, Facebook, LinkedIn, Twitter, etc. A wide selection of journals (inclusive of 9 subjects, more than 200 journals)

Providing 24-hour high-quality service

User-friendly online submission system

Fair and swift peer-review system

Efficient typesetting and proofreading procedure

Display of the result of downloads and visits, as well as the number of cited articles

Maximum dissemination of your research work

Submit your manuscript at: http://papersubmission.scirp.org/

Or contact ajibm@scirp.org 